\title{
POTENTIAL OF THE ESA23B MAIZE POPULATION FOR PROTEIN AND OIL CONTENT IMPROVEMENT
}

\author{
Andréa Mittelmann ${ }^{1,4 *}$; José Branco de Miranda Filho²; Gustavo Júlio Mello Monteiro de Lima; \\ Claudete Hara-Klein ${ }^{3}$; Ricardo Takao Tanaka ${ }^{5}$ \\ ${ }^{I}$ Embrapa Gado de Leite, C.P. 403 - 96001-970 - Pelotas, RS - Brasil. \\ ${ }^{2}$ USP/ESALQ - Depto. de Genética, C.P. 83 - CEP: 13400-970 - Piracicaba, SP - Brasil. \\ ${ }_{4}^{3}$ Embrapa Suínos e Aves, C.P. 21 - 89700-000 - Concórdia, SC - Brasil. \\ ${ }_{5}^{4}$ CAPES scholar. \\ FAPESP scholar. \\ *Corresponding author <andream@cpact.embrapa.br>
}

\begin{abstract}
Among the traits that may add commercial value to maize (Zea mays L.), those related to nutritional quality, specially protein and oil content, are of great interest to the feed industry. The objective of this work was studying the variability of protein and oil content, as well as yield, in a group of maize testcrosses. One hundred and twenty $\mathrm{S}_{1}$ families of the ESA23B maize population were crossed with two testers, an openpollinated population (BR108) and an exotic line (CML269). Testcrosses were evaluated at two locations under a completely randomized block design with three replications. Ear and grain yield, protein and oil content were evaluated. The three-way interaction location $\mathrm{x}$ tester $\mathrm{x}$ progeny was significant for all traits, except for oil content. Differences among progenies were detected for all traits. Testcross means varied from $8.40 \%$ to $11.82 \%$ for protein content and from $3.77 \%$ to $5.10 \%$ for oil content. Hybrids with similar or superior means to the best check were identified for protein content, ear yield, and grain yield. Estimates of the interpopulation additive variance ranged from 0.553 to 1.124 for protein content; 0.034 to 0.057 for oil content (percent data); 132.13 to 521.74 for ear yield and 116.33 to 381.73 for grain yield (data in grams per plant). The population ESA23B can potentially be improved for all the traits studied. Associations among traits were weak, thus concomitant selection of quality and yield can be feasible.
\end{abstract}

Key words: Zea mays, breeding, topcross, nutritional quality, grains

\section{POTENCIAL DA POPULAÇÃO DE MILHO ESA23B PARA O MELHORAMENTO DOS TEORES DE PROTEÍNA E ÓLEO}

\begin{abstract}
RESUMO: Entre as características capazes de adicionar valor comercial ao milho (Zea mays L.), estão aquelas relacionadas à qualidade nutricional, com destaque para os teores de proteína e óleo. O objetivo deste trabalho foi verificar a variabilidade existente para teor de proteína e teor de óleo, além da produtividade, em um conjunto de testcrosses. Foram avaliadas 120 famílias $S_{1}$ da população de milho ESA23B em cruzamento com dois testadores, sendo uma variedade de polinização aberta (BR108) e uma linhagem exótica (CML269). Os ensaios foram realizados em dois locais, em blocos casualizados com três repetições. Foram avaliados peso de espigas, peso de grãos, teor de proteína e teor de óleo. A interação tripla local x testador x progênie foi significativa, exceto para o teor de óleo. Houve diferença entre progênies para todos os caracteres. As médias dos testcrosses variaram de $8,40 \%$ a $11,82 \%$ para teor de proteína e de 3,77\% a 5,10\% para teor de óleo. Testcrosses com média semelhante ou superior à da melhor testemunha foram identificados para teor de proteína, peso de espigas e peso de grãos. As estimativas da variância aditiva interpopulacional foram de 0,553 a 1,124 para teor de proteína; 0,034 a 0,057 para teor de óleo (dados em percentual); 132,13 a 521,74 para peso de espigas e 116,33 a 381,73 para peso de grãos (dados em gramas por planta). A população ESA23B possui potencial para o melhoramento dos caracteres avaliados. As associações entre caracteres foram fracas, indicando a possibilidade de seleção simultânea para qualidade e rendimento.

Palavras-chave: Zea mays, melhoramento vegetal, topcross, qualidade nutricional, grãos
\end{abstract}

\section{INTRODUCTION}

Maize breeding programs have always concentrated efforts on increasing yield. Other traits directly related to yield, such as plant architecture and resistance to pests and diseases have also been prioritized to attend the needs of maize growers. The main use of maize in
Brazil is for animal feeding, in the form of rations. Therefore, the development of cultivars to supply the needs of the agrindustrial chain represents a possibility of adding value to the product. Some of the most important traits of interest in the maize market are those related to the nutricional quality of the grains, especially protein and oil content. 
The protein content is a quantitative trait and several studies have pointed that there is a great number of genes involved in its control. Dudley \& Lambert (1992) estimated that there are 173 genes affecting this trait. In a study of quantitative trait loci (QTLs) involving 80 markers regularly spaced in the maize genome, sixteen markers grouped in eight regions had been associated to the protein content (Berke \& Rocheford, 1995). Additive and non-additive effects are important and dominance occurs essentially for the reduction of the trait (East \& Jones, 1920; Sreeramulu \& Bauman, 1970; Berke \& Rocheford, 1995).

Significant environment and genotype $\mathrm{x}$ environment interaction effects are, in general, detected for protein content (Genter et al., 1956; Berke \& Rocheford, 1995). Among the environment factors that influence protein content, temperature and availability of water and nitrogen in the soil are the most important (East \& Jones, 1920; Oikeh et al., 1998). Plant genotype, but not pollen genotype, is the main determinant for grain protein content (East \& Jones, 1920; Letchworth \& Lambert, 1998).

The existence of genetic variability and the prospect of selection for protein content in maize have been demonstrated in several studies (Dudley, 1977; Dudley \& Lambert, 1992; Micu et al., 1995). After seventy-six generations of divergent mass selection in Burr's White population, the increase in protein content was $139 \%$, or 20 times the standard deviation of the original population, without the exhaustion of genetic variability (Dudley, 1977). After 90 generations of selection, the last 25 cycles were evaluated in the same experiment. The average gain by selection cycle was of $0.13 \pm 0.02$ percentile points (Dudley \& Lambert, 1992). In another work, samples with high protein content (12-15\%) have been identified between local populations from Moldove. After 12 years of recurrent selection, lines with up to 23$24 \%$ of protein were obtained, without genetic variability being exhausted (Micu et al., 1995).

The oil content in the maize grains is also a quantitative trait (Dudley, 1977). Berke \& Rocheford (1995) detected 31 RFLP loci associated to oil content; however, seven of these loci had answered for $61 \%$ of the total genotypic variation for oil content, in spite of the extreme divergence of the parents of this cross. Similarly, the oil content seems to be less influenced by the effects of environment and genotype $\mathrm{x}$ environment interaction than the protein content (Genter et al., 1956; Berke \& Rocheford, 1995).

The additive genetic variance seems to be the main component in the control of this trait (Dudley, 1977). The maternal control, i. e., the influence of the female parent genotype, has been suggested as the predominant effect in the determination of oil content in maize grains (Miller \& Brimhall, 1951; Garwood et al., 1970; Batista \& Tosello, 1982). However, influence of the male parent genotype also occurs, through xenia effect (Miller \& Brimhall, 1951; Alexander \& Lambert, 1968; Letchworth \& Lambert, 1998).

Several works have proven the efficiency of recurrent selection for the increase of the oil content (Misevic \& Alexander, 1989; Dudley \& Lambert, 1992; Song et al., 1999). In an experiment conducted at the University of Illinois, with 90 cycles of selection, the population Illinois High Oil (IHO) increased from $4.7 \%$ to $19.3 \%$ of oil, representing a gain of approximately 22 times the additive standard deviation of the original population. The average gain by selection cycle was of 0.14 \pm 0.02 percentile points and the number of genes contributing for the trait was estimated in 69 (Dudley \& Lambert, 1992). The selection of individual grains was used in the Zhongzong n. 2 population, allowing to reach $11.25 \%$ of oil after eleven cycles of selection, that corresponded to 2.39 times the mean or 8.6 times the standard deviation of the original population (Song et al., 1999). In the same way, 24 cycles of selection in the population Alexho Synthetic had allowed an increase in oil content from $5 \%$ to $17 \%$, or 0.49 percentile points for each cycle (Misevic \& Alexander, 1989). Signs of exhaustion of the genetic variability for oil content were not observed at the above mentioned studies.

The topcross design was proposed by Davis (1927) and Jenkins \& Brunson (1932) and is widely used in the development of new hybrid combinations and in recurrent selection (Miranda Filho \& Gorgulho, 2001). This scheme of evaluation allows progeny comparisons as far as their combining ability with a tester.

Therefore, the objective of this work was to estimate genetic variability for protein and oil content and yield, in a set of maize testcrosses originated from the crossing of $S_{1}$ families of population ESA23B with two testers.

\section{MATERIAL AND METHODS}

The ESA23B population, with white endosperm, was selected by the USP/ESALQ maize breeding program. It has good adaptation and good performance for agronomic traits. In this experiment, $120 \mathrm{~S}_{1}$ families derived from this population were tested in topcross with an open polinated cultivar (BR 108) and an exotic endogamic line (CML269) from International Center of Improvement of Maize and Wheat, Mexico (CIMMYT ).

The crossings were carried out at Piracicaba, during the summer of $1998 / 1999$. The $\mathrm{S}_{1}$ families were used as female parents. Two, 3-m long rows of each family were sown, spaced $0.9 \mathrm{~m}$ between rows and $0.2 \mathrm{~m}$ between plants. At least five ears of each family were hand polinated with each one of the testers. A number of 113 testcrosses for each tester was obtained. Some families differed between testers. 
In the summer of 1999/2000 the testcrosses were evaluated at two locations: Experimental Station of Anhembi $\left(22^{\circ} 45^{\prime} \mathrm{S} ; 48^{\circ} \mathrm{W}\right)$ and Experimental Station of

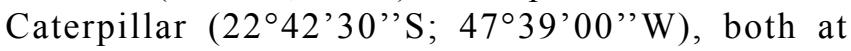
Piracicaba, SP, Brazil. The experiments were conducted using a completely randomized block design with three replicates. Each plot was composed of one, 4-m long row, spaced $0.9 \mathrm{~m}$ between plots and $0.2 \mathrm{~m}$ between plants. The hybrids Master (Novartis) and BR 2121 (EMBRAPA) were inserted as checks in a systematic way, one to each ten plots of testcrosses. Master is a triple hybrid of normal endosperm and BR 2121 is a double hybrid of type Quality Protein Maize (QPM), i.e., contains the opaque$2\left(\mathrm{O}_{2}\right)$ mutant gene. In intercalated plots of BR 2121 (one to each twenty plots of testcrosses) five ears were hand polinated with pollen of the same hybrid, to guarantee the expression of the recessive gene $o_{2}$. In these plots, only the polinated ears have been harvested.

Ear yield (EY) and grain yield (GY) were measured and corrected to an ideal stand of 20 plants per plot by the covariance method. A sample of $50 \mathrm{~g}$ of grains, representative of the plot, was sent to chemical analyses. Protein and oil analyses were performed on ground samples and analysed by near infrared reflectance spectroscopy (NIR) using a NIRSystem 6500 equipment with calibration curves developed in the laboratory. The methodology used for obtaining calibration curves followed procedures recommended by the Association of Official Analytical Chemists (AOAC, 1995), i.e., dry matter, by oven drying at $105^{\circ} \mathrm{C}$ overnight; protein, by Kjeldahl method; oil, by ether extraction in a Soxhlet equipment. Protein and oil values were adjusted to dry matter.

The estimates of parameters for the calibration curves are presented in Table 1. After the calibration, 20 samples were analyzed by standard laboratorial procedures and the values compared to those predicted by NIR. The correlation coefficient between methods was 0.96 for protein content and 0.71 for oil content.

Individual analyses of variance were performed for each combination of tester and location. A combined analysis and analyses grouped by location and by tester

Table 1 - Estimates of NIR calibration equation parameters for dry matter, protein and oil content.

\begin{tabular}{lccccc}
\hline Trait & $\mathrm{N}$ & $\mathrm{SEC}$ & $\mathrm{R}^{2}$ & $\mathrm{SECV}$ & $\mathrm{R}_{1}{ }^{2}$ \\
\hline 1. Dry matter & 115 & 0.28 & 0.80 & 0.32 & 0.74 \\
2. Protein & 117 & 0.14 & 0.96 & 0.19 & 0.94 \\
3. Oil & 103 & 0.17 & 0.75 & 0.28 & 0.52 \\
\hline
\end{tabular}

$\mathrm{N}=$ number of samples used in calibration

$\mathrm{SEC}=$ calibration standard error

$\mathrm{R}^{2}=$ determination coeficient for the regression between lab values and reflectance values

$\mathrm{SECV}=$ validation standard error

$\mathrm{R}_{1}^{2}=$ determination coeficient of validation were also performed. Tester and location were fitted as fixed and families fitted as random.

In the individual analyses of variance, $\sigma_{t}^{2}$ is the genetic variance between testcrosses. This is defined at the interpopulation level and is a function of one of the homologous of the interpopulation additive variance, $\sigma_{\mathrm{t}}^{2}=[(1+\mathrm{F}) / 4] \sigma_{\mathrm{A} 12}^{2}, \mathrm{~F}$ being the family endogamy coefficient. In the present study $\mathrm{F}=0$ in the $\mathrm{S}_{0}$ plants that gave origin to the $S_{1}$ families. In this way, the estimate $\hat{\sigma}_{\mathrm{A} 12}^{2}=4 \hat{\sigma}_{\mathrm{t}}^{2}$ was obtained, where $\hat{\sigma}_{\mathrm{A} 12}^{2}$ refers to the nonendogamous populations, i.e., $\mathrm{S}_{0}$ genotypes and tester. In terms of population structure, considering one locus with two alleles, $\sigma_{\mathrm{A} 12}^{2}=2 \mathrm{p}(1-\mathrm{p})[\mathrm{a}+(1-2 \mathrm{t}) \mathrm{d}]^{2}, p$ being the frequency of the favorable allele in the base population; $t$ the frequency of the same allele in the tester; $a$ the half of the difference among the genotypic values of the homozygotes and $d$ a dominance deviation (Miranda Filho \& Gorgulho, 2001).

Selection progress was estimated considering truncated selection with $10 \%$ intensity. The results are presented in absolute values, in the unit of the trait measurement (Gs), and as percentage relative to the overall mean of testcrosses (Gs\%). The sensitivity to detect differences among testcrosses was compared by the test of Schumann \& Bradley (1959), based on F test values for the testcross effect. Testcross means were compared by the Scott-Knott test and with the best check by t-test, both at $5 \%$ of probability. Phenotypic correlations between traits were estimated within each experiment.

\section{RESULTS AND DISCUSSION}

Testcrosses differed for all experiments and traits, except for ear weight in the experiment involving the BR 108 tester at Anhembi (Table 2). This experiment presented a greater coefficient of variation for ear and grain yield. Faillures in the weed control were observed only in this experiment, which may have increased the experimental error and hampered the identification of differences among treatments.

In the combined analysis involving the two locations and two testers, the effect of the triple interaction involving locations, testers and families was significant for all the traits, except for oil content (Table 3). Therefore, all other results were obtained separately by experiment. Family effects were not found in the combined analysis, reflecting the fact that differences detected in individual analyses were not uniform for all the experiments. Spearman correlations comparing the ranking of the families in the four experiments also demonstrated the existence of a complex-type genotype $x$ environment interaction, attributed to changes in the genotype rank (data not shown). In most cases, these correlations were non-significant $(P>0,05)$. Likewise, in the analyses grouped by location, tester $\mathrm{x}$ family interaction was sig- 
Table 2 - Individual analyses of variance for protein content, oil content, ear yield (EY) and grain yield (GY).

\begin{tabular}{|c|c|c|c|c|c|c|c|c|}
\hline \multirow{3}{*}{ F.V. } & \multicolumn{4}{|c|}{ Anhembi } & \multicolumn{4}{|c|}{ Caterpillar } \\
\hline & \multicolumn{2}{|c|}{ BR 108} & \multicolumn{2}{|c|}{ CML269 } & \multicolumn{2}{|c|}{ BR 108} & \multicolumn{2}{|c|}{ CML269 } \\
\hline & d.f. & MS & d.f. & MS & d.f. & MS & d.f. & MS \\
\hline \multicolumn{9}{|c|}{ Protein $(\%)$} \\
\hline Block & 2 & $2.54 * *$ & 2 & $3.42 * *$ & 2 & $1.99 * *$ & 2 & 0.19 \\
\hline Testcross & 112 & $0.87 * *$ & 112 & $0.88 * *$ & 112 & $0.62 * *$ & 112 & $0.94 * *$ \\
\hline Error & 186 & 0.44 & 190 & 0.38 & 191 & 0.24 & 191 & 0.18 \\
\hline C.V. & & 6.88 & & 6.27 & & 4.78 & & 4.04 \\
\hline $\mathrm{R}^{2}$ & & 0.56 & & 0.60 & & 0.61 & & 0.76 \\
\hline \multicolumn{9}{|l|}{ OIL (\%) } \\
\hline Block & 2 & 0.048 & 2 & $1.111 * *$ & 2 & 0.037 & 2 & 0.027 \\
\hline Testcross & 112 & $0.060 * *$ & 112 & $0.052 * *$ & 112 & $0.059 * *$ & 112 & $0.050 * *$ \\
\hline Error & 186 & 0.030 & 190 & 0.024 & 191 & 0.020 & 191 & 0.027 \\
\hline C.V. & & 4.08 & & 3.49 & & 3.20 & & 3.52 \\
\hline $\mathrm{R}^{2}$ & & 0.55 & & 0.64 & & 0.64 & & 0.52 \\
\hline \multicolumn{9}{|l|}{$\mathrm{EY}\left(\mathrm{g} \mathrm{pl}^{-1}\right)$} \\
\hline Block & 2 & $3731.84 * *$ & 2 & $2673.34 * *$ & 2 & $11084.06^{* *}$ & 2 & $996.77^{*}$ \\
\hline Testcross & 112 & 477.48 & 112 & $505.64 * *$ & 112 & $714.02 * *$ & 112 & $609.27 * *$ \\
\hline Error & 219 & 379.86 & 220 & 236.76 & 220 & 327.37 & 219 & 305.79 \\
\hline C.V. & & 23.80 & & 15.56 & & 12.93 & & 10.15 \\
\hline $\mathrm{R}^{2}$ & & 0.42 & & 0.54 & & 0.59 & & 0.51 \\
\hline \multicolumn{9}{|l|}{$\overline{\mathrm{GY}}\left(\mathrm{g} \mathrm{pl}^{-1}\right)$} \\
\hline Block & 2 & $2690.64 * *$ & 2 & $1967.90 * *$ & 2 & $7339.07 * *$ & 2 & $970.94 *$ \\
\hline Testcross & 112 & $356.11 *$ & 112 & $358.85 * *$ & 112 & $517.67 * *$ & 112 & $375.32 * *$ \\
\hline Error & 219 & 270.16 & 219 & 159.97 & 220 & 234.78 & 221 & 217.44 \\
\hline C.V. & & 25.66 & & 16.38 & & 13.54 & & 10.82 \\
\hline$\underline{\mathrm{R}^{2}}$ & & 0.43 & & 0.56 & & 0.58 & & 0.48 \\
\hline
\end{tabular}

**, * significant by F-test at 1 and 5\%, respectively.

Table 3 - Combined analyses of variance for protein content, oil content, ear yield (EY) and grain yield (GY).

\begin{tabular}{|c|c|c|c|c|c|c|c|c|}
\hline \multirow{2}{*}{ F. V. } & \multicolumn{2}{|c|}{ Protein } & \multicolumn{2}{|c|}{ Oil } & \multicolumn{2}{|r|}{ EY } & \multicolumn{2}{|c|}{ GY } \\
\hline & d.f. & MS & d.f. & MS & d.f. & MS & d.f. & MS \\
\hline & $\cdots-\cdots$ & - - & $\cdots-\cdots$ & 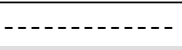 & $-\cdots \cdots$ & - & $-1-\ldots$ & - \\
\hline Block/L/T & 8 & $2.0377 * *$ & 8 & $0.3059 * *$ & 8 & $4621.50 * *$ & 8 & $3242.14 * *$ \\
\hline Location (L) & 1 & $92.6693 * *$ & 1 & $10.4906 * *$ & 1 & $1421569.22 * *$ & 1 & $965105.76 * *$ \\
\hline Tester $(\mathrm{T})$ & 1 & 2.0648 & 1 & $18.8001 * *$ & 1 & $185900.94 * *$ & 1 & $100885.98 * *$ \\
\hline Family (F) & 119 & 1.1222 & 119 & $0.0957 * *$ & 119 & 689.81 & 119 & 476.27 \\
\hline $\mathrm{L} \times \mathrm{T}$ & 1 & 1.7171 & 1 & 0.0029 & 1 & $19407.41 * *$ & 1 & $8341.66 * *$ \\
\hline $\mathrm{L} \times \mathrm{F}$ & 119 & 0.5371 & 119 & 0.0270 & 119 & 418.51 & 119 & 288.49 \\
\hline $\mathrm{T} \times \mathrm{F}$ & 105 & $1.1414 * *$ & 105 & $0.0567 * *$ & 105 & 635.33 & 105 & 455.11 \\
\hline$L \times T \times F$ & 105 & $0.4507 * *$ & 105 & 0.0295 & 105 & $564.82 * *$ & 105 & $390.37 * *$ \\
\hline error & 758 & 0.3120 & 758 & 0.0253 & 878 & 312.37 & 879 & 220.59 \\
\hline$\overline{\mathrm{R}^{2}}$ & & 0.68 & & 0.76 & & 0.88 & & 0.87 \\
\hline C.V. & & 5.53 & & 3.57 & & 14.34 & & 15.20 \\
\hline
\end{tabular}

**, * significant by F-test at 1 and 5\%, respectively.

nificant (Table 4). In the analyses grouped by tester, location $\mathrm{x}$ family interaction was significant, except for oil content (Table 5). The presence of this type of interaction makes difficult the selection of the families that will be recombined in order to give origin to a new cycle of recurrent selection. Only oil content could be selected on the basis of the average of the two locations; however, testers need to be considered separately.
Tester effect was significant in the analysis grouped by location, except for the protein content at Caterpillar, and CML269 presented higher means (Table 6). The analysis grouped by tester evidenced the importance of the location effect. The environment of Caterpillar Experimental Station was more favorable, probably because of higher fertility levels, leading to higher means for all traits (Tables 5 and 6). 
Table 4 - Analyses of variance grouped by location for protein content, oil content, ear yield (EY) and grain yield (GY).

\begin{tabular}{|c|c|c|c|c|c|c|c|c|}
\hline \multirow{2}{*}{ F. V. } & \multicolumn{2}{|c|}{ Protein } & \multicolumn{2}{|c|}{ Oil } & \multicolumn{2}{|c|}{ EY } & \multicolumn{2}{|c|}{ GY } \\
\hline & d.f. & MS & d.f. & MS & d.f. & MS & d.f. & MS \\
\hline & --- & 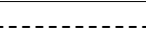 & $b-\cdots$ & 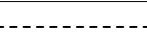 & $-\cdots$ & 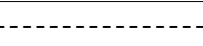 & $\left.\right|^{-1}-\ldots$ & (-........ \\
\hline \multicolumn{9}{|l|}{ ANHEMBI } \\
\hline Block/T & 4 & $2.9866 * *$ & 4 & $0.5796 * *$ & 4 & $3202.59 * *$ & 4 & $2329.27 * *$ \\
\hline Tester $(\mathrm{T})$ & 1 & $3.7176 *$ & 1 & $9.0319 * *$ & 1 & $42539.16 * *$ & 1 & $25485.72 * *$ \\
\hline Family (F) & 119 & 0.9384 & 119 & 0.0575 & 119 & 485.60 & 119 & 353.11 \\
\hline$T \times F$ & 105 & $0.7789 * *$ & 105 & $0.0490 * *$ & 105 & $497.72 * *$ & 105 & $360.92 * *$ \\
\hline Average error & 376 & 0.4141 & 376 & 0.0270 & 439 & 308.15 & 438 & 215.06 \\
\hline $\mathrm{R} 2$ & & 0.58 & & 0.72 & & 0.60 & & 0.56 \\
\hline C.V. & & 6.56 & & 3.77 & & 19.42 & & 20.77 \\
\hline \multicolumn{9}{|c|}{ CATERPILLAR } \\
\hline Block/T & 4 & $1.0888 * *$ & 4 & 0.0321 & 4 & $6040.42 * *$ & 4 & $4155.00 * *$ \\
\hline Tester $(\mathrm{T})$ & 1 & 0.0081 & 1 & $9.7825 * *$ & 1 & $162909.48 * *$ & 1 & $84014.06 * *$ \\
\hline Family (F) & 119 & 0.7529 & 119 & $0.0666 * *$ & 119 & 623.71 & 119 & 413.89 \\
\hline $\mathrm{T} \times \mathrm{F}$ & 105 & $0.8025 * *$ & 105 & $0.0364 * *$ & 105 & $702.73 * *$ & 105 & $484.02 * *$ \\
\hline Average error & 382 & 0.2115 & 382 & 0.0236 & 439 & 316.60 & 441 & 226.09 \\
\hline $\mathrm{R} 2$ & & 0.69 & & 0.71 & & 0.71 & & 0.67 \\
\hline C.V. & & 4.42 & & 3.37 & & 11.40 & & 12.05 \\
\hline
\end{tabular}

**, * significant by $\mathrm{F}$-test at 1 and $5 \%$, respectively.

Table 5 - Analyses of variance grouped by tester for protein content, oil content, ear yield (EY) and grain yield (GY).

\begin{tabular}{|c|c|c|c|c|c|c|c|c|}
\hline \multirow{2}{*}{ F. V. } & \multicolumn{2}{|c|}{ Protein } & \multicolumn{2}{|c|}{ Oil } & \multicolumn{2}{|c|}{ EY } & \multicolumn{2}{|c|}{ GY } \\
\hline & d.f. & MS & d.f. & MS & d.f. & MS & d.f. & MS \\
\hline & $-\cdots$ & , &.-- & - & - & 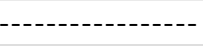 & $\left.\right|^{1}-\ldots$ & - \\
\hline \multicolumn{9}{|l|}{ BR 108} \\
\hline Block/L & 4 & $2.2689 * *$ & 4 & 0.0424 & 4 & $7407.95 * *$ & 4 & $5014.86 * *$ \\
\hline Location (L) & 1 & $63.0466 * *$ & 1 & $5.3039 * *$ & 1 & $564085.00 * *$ & 1 & $403181.20 * *$ \\
\hline Family (F) & 112 & $1.0156 * *$ & 112 & $0.0889 * *$ & 112 & 654.34 & 112 & 467.61 \\
\hline$L \times F$ & 112 & $0.4989 * *$ & 112 & 0.0284 & 112 & $533.80 * *$ & 112 & $403.06 * *$ \\
\hline error & 377 & 0.3437 & 377 & 0.0248 & 439 & 353.56 & 439 & 252.43 \\
\hline $\mathrm{R}^{2}$ & & 0.66 & & 0.68 & & 0.82 & & 0.82 \\
\hline C.V. & & 5.83 & & 3.64 & & 16.94 & & 17.92 \\
\hline \multicolumn{9}{|l|}{ CML269 } \\
\hline Block/L & 4 & $1.8066 * *$ & 4 & $0.5694 * *$ & 4 & $1835.06 * *$ & 4 & $1469.42 * *$ \\
\hline Location (L) & 1 & $35.0834 * *$ & 1 & $5.4242 * *$ & 1 & $898023.19 * *$ & 1 & $584037.40 * *$ \\
\hline Family (F) & 112 & $1.2744 * *$ & 112 & $0.0715 * *$ & 112 & $674.08 *$ & 112 & $465.81 * *$ \\
\hline$L \times F$ & 112 & $0.4962 * *$ & 112 & 0.0288 & 112 & $442.47 * *$ & 112 & $269.43 * *$ \\
\hline error & 381 & 0.2806 & 381 & 0.0258 & 439 & 271.19 & 440 & 188.83 \\
\hline $\mathrm{R}^{2}$ & & 0.70 & & 0.67 & & 0.90 & & 0.89 \\
\hline C.V. & & 5.22 & & 3.50 & & 12.15 & & 12.86 \\
\hline
\end{tabular}

**, * significant by F-test at 1 and 5\%, respectively.

The higher heterosis obtained in crossings involving CML 269, with higher means for all traits, may have result from the fact that it is an endogamic line. It is also exotic and, therefore, probably more divergent from population ESA23B than the tester BR 108. In all the experiments, the hand-polinated BR 2121 check (pollen of the same genotype) was superior for protein and oil content (Table 6). In general, there was also difference in protein and oil content between wind- polinated BR 2121 and Master. For ear and grain yield, only wind-polinated BR 2121 and Master were considered as checks. Master was superior for ear yield in two experiments and for grain yield in all the experiments. The mean, minimum and maximum values reached by testcrosses for each experiment are shown in Table 6. Check BR 2121 is a double hybrid of QPM type, carrying the mutant gene $o_{2}$, that confers higher content of lysine and triptophan and an increase in the embryo size. 
This larger embryo size tends to increase the oil content of the grain.

The mean protein content of the testcrosses, ranged from $8.40 \%$ to $11.82 \%$. Most of them were above the average of all samples analyzed in the same laboratory (EMBRAPA, 1991). The mean obtained in another work conducted in the region was of $9.82 \%$ (BraquíticoOpaco VD Composite, Zimback, 1985). For oil content,

Table 6 - Mean, minimum and maximum values of the testcrosses for protein content, oil content, ear yield (EY) and grain yield (GY).

\begin{tabular}{lrrrr}
\hline \multirow{2}{*}{ Trait } & \multicolumn{2}{c}{ Anhembi } & \multicolumn{2}{c}{ Caterpillar } \\
\cline { 2 - 5 } & BR 108 & CML269 & BR 108 & CML269 \\
\hline Protein (\%) & & & & \\
BR 2121 $\otimes$ & $11.06 \mathrm{a}^{\#}$ & $10.25 \mathrm{a}$ & $10.27 \mathrm{a}$ & $10.24 \mathrm{a}$ \\
BR 2121 X & $8.59 \mathrm{~b}$ & $9.14 \mathrm{~b}$ & $9.56 \mathrm{~b}$ & $9.66 \mathrm{~b}$ \\
Master & $8.27 \mathrm{~b}$ & $8.68 \mathrm{c}$ & $9.14 \mathrm{c}$ & $9.08 \mathrm{c}$ \\
Testcrosses & & & & \\
Mean & 9.72 & 9.89 & 10.39 & 10.39 \\
Minimum & 8.40 & 8.72 & 9.23 & 8.74 \\
Maximum & 11.51 & 11.36 & 11.42 & 11.82 \\
\hline OIL $(\%)$ & & & & \\
BR 2121 $\otimes$ & $5.49 \mathrm{a}$ & $5.24 \mathrm{a}$ & $6.17 \mathrm{a}$ & $6.15 \mathrm{a}$ \\
BR 2121 X & $5.02 \mathrm{~b}$ & $5.08 \mathrm{~b}$ & $6.00 \mathrm{~b}$ & $5.83 \mathrm{~b}$ \\
Master & $4.26 \mathrm{c}$ & $4.29 \mathrm{c}$ & $4.71 \mathrm{c}$ & $4.78 \mathrm{c}$ \\
Testcrosses & & & & \\
Mean & 4.22 & 4.48 & 4.41 & 4.68 \\
Minimum & 3.77 & 4.03 & 3.93 & 4.28 \\
Maximum & 4.56 & 4.86 & 4.71 & 5.10 \\
\hline EY (t ha $\left.{ }^{-1}\right)$ & & & & \\
BR 2121 X & $4.61 \mathrm{~b}$ & $5.24 \mathrm{a}$ & $6.96 \mathrm{~b}$ & $8.56 \mathrm{a}$ \\
Master & $5.25 \mathrm{a}$ & $5.55 \mathrm{a}$ & $7.59 \mathrm{a}$ & $8.91 \mathrm{a}$ \\
Testcrosses & & & & \\
Mean & 3.64 & 4.39 & 6.22 & 7.65 \\
Minimum & 2.64 & 2.88 & 4.73 & 6.28 \\
Maximum & 5.29 & 5.86 & 8.21 & 9.72 \\
\hline GY (t ha $\left.{ }^{-1}\right)$ & & & & \\
BR 2121 X & $3.63 \mathrm{~b}$ & $4.16 \mathrm{~b}$ & $5.59 \mathrm{~b}$ & $6.87 \mathrm{~b}$ \\
Master & $4.46 \mathrm{a}$ & $4.68 \mathrm{a}$ & $6.33 \mathrm{a}$ & $7.36 \mathrm{a}$ \\
Testcrosses & & & & \\
Mean & 2.84 & 3.43 & 5.03 & 6.06 \\
Minimum & 2.03 & 2.23 & 3.82 & 4.92 \\
Maximum & 4.30 & 4.83 & 6.70 & 7.52 \\
Check & & & & \\
\hline
\end{tabular}

"Check means followed by the same letter do not differ by t-test at $5 \%$. means varied from $3.77 \%$ to $5,10 \%$. The average of 266 analyses of maize from different origins was of $3.84 \%$ (EMBRAPA, 1991). Silva (1990) observed means of 4.79\% (Piranão VD-2) and 5.06\% (Piranão VF-1). In population ESALQ VD-2, a mean of $5.38 \%$ oil was obtained for self-polinated ears (Batista, 1980).

Each testcross mean was compared by t-test with the best check, for each trait and experiment (Table 7). For protein content, 20 to $80 \%$ of the testcrosses presented similar means in relation to the best check. Some testcrosses were superior when compared to the best check, being $1.8 \%$ of testcrosses in the experiment with tester CML269 at Anhembi, 14\% in the experiment with tester BR108 at Caterpillar, and $18 \%$ in the experiment with tester CML269 at Caterpillar. Testcross oil content means were all inferior than the best check mean. However, check BR 2121 is a genotype of high nutritional quality that, in this study, presented from 0.95 to 1.46 percentile points ( 22 to $31 \%$ ) above the other check for oil content. This check exceeded the value of $6 \%$ of oil content, considered as the minimum criterion for inclusion in the commercial category of High Oil Maize (U.S. Grain Council, 1999), being a difficult standard to be reached in the absence of specific selection for the trait. On the average, testcrosses were similar to the Master check for oil content. Several testcrosses with similar mean in relation to the best check were detected, either for ear yield (18 to $31 \%$ of testcrosses, according to experiment), or for grain yield (11 to $26 \%$ ).

For protein content, the experiment with the tester CML269 at Caterpillar presented higher ability to discriminate families (Table 8). However, for oil content, this was the experiment with least sensitivity. The best combination for oil content involved BR 108 tester at Caterpillar. For ear and grain yield, the BR 108 tester at Anhembi had less sensitivity than all other experiments. The magnitudes of interpopulation additive variance estimates were related to these differences.

Estimates of interpopulation additive variance were significant, except for ear and grain yield in the experiment with the BR108 tester at Anhembi (Table 8). In general, estimates of additive variance for oil content were low ( 0.034 or 0.057 , for oil percentage), when

Table 7 - Number of testcrosses with superior $(>)$, equal $(=)$ and inferior $(<)$ means compared to the best check by t-test at $5 \%$ probability, for protein content, oil content, ear yield (EY) and grain yield (GY).

\begin{tabular}{|c|c|c|c|c|c|c|c|c|c|c|c|c|}
\hline \multirow{3}{*}{ Trait } & \multicolumn{6}{|c|}{ Anhembi } & \multicolumn{6}{|c|}{ Caterpillar } \\
\hline & \multicolumn{3}{|c|}{ BR 108} & \multicolumn{3}{|c|}{ CML269 } & \multicolumn{3}{|c|}{ BR 108} & \multicolumn{3}{|c|}{ CML269 } \\
\hline & $>$ & $=$ & $<$ & $>$ & $=$ & $<$ & $>$ & $=$ & $<$ & $>$ & $=$ & $<$ \\
\hline Protein & 0 & 23 & 90 & 2 & 79 & 32 & 16 & 91 & 6 & 20 & 83 & 10 \\
\hline OIL & 0 & 0 & 113 & 0 & 0 & 113 & 0 & 0 & 113 & 0 & 0 & 113 \\
\hline EY & 0 & 20 & 93 & 0 & 33 & 80 & 0 & 35 & 78 & 0 & 35 & 78 \\
\hline GY & 0 & 12 & 101 & 0 & 18 & 95 & 0 & 30 & 83 & 0 & 16 & 97 \\
\hline
\end{tabular}


Table 8 - F-test values for the testcross effect, interpopulation additive variance, expected genetic gain in absolute value (Gs) and in percentage (Gs\%) for protein content, oil content, ear yield (EY) and grain yield (GY).

\begin{tabular}{|c|c|c|c|c|}
\hline \multirow{2}{*}{ Trait } & \multicolumn{2}{|c|}{ Anhembi } & \multicolumn{2}{|c|}{ Caterpillar } \\
\hline & BR108 & CML269 & BR108 & CML269 \\
\hline \multicolumn{5}{|c|}{ Protein } \\
\hline $\mathrm{F}$ & $1.96 \mathrm{~b}^{\#}$ & $2.29 \mathrm{~b}$ & $2.52 \mathrm{~b}$ & $5.31 \mathrm{a}$ \\
\hline$\sigma_{\mathrm{A} 12}^{2}$ & $0.640 \pm 0.186$ & $0.737 \pm 0.183$ & $0.553 \pm 0.127$ & $1.124 \pm 0.185$ \\
\hline Gs & 0.40 & 0.48 & 0.44 & 0.93 \\
\hline Gs $\%$ & 4.07 & 4.86 & 4.28 & 8.97 \\
\hline \multicolumn{5}{|l|}{ OIL } \\
\hline $\mathrm{F}$ & $2.02 \mathrm{ab}$ & $2.13 \mathrm{ab}$ & $2.92 \mathrm{a}$ & $1.85 \mathrm{~b}$ \\
\hline$\sigma_{\mathrm{A} 12}^{2}$ & $0.045 \pm 0.013$ & $0.041 \pm 0.011$ & $0.057 \pm 0.012$ & $0.034 \pm 0.011$ \\
\hline Gs & 0.11 & 0.11 & 0.16 & 0.09 \\
\hline Gs $\%$ & 2.56 & 2.38 & 3.56 & 1.83 \\
\hline \multicolumn{5}{|l|}{ EY } \\
\hline $\mathrm{F}$ & $1.26 \mathrm{~b}$ & $2.14 \mathrm{a}$ & $2.18 \mathrm{a}$ & $1.99 \mathrm{a}$ \\
\hline$\sigma_{\mathrm{A} 12}^{2}$ & $132.13 \pm 98.48$ & $362.83 \pm 95.28$ & $521.74 \pm 134.27$ & $410.76 \pm 116.04$ \\
\hline Gs & 2.93 & 9.74 & 11.88 & 9.77 \\
\hline Gs $\%$ & 3.58 & 9.85 & 8.49 & 5.67 \\
\hline \multicolumn{5}{|l|}{ GY } \\
\hline $\mathrm{F}$ & $1.32 \mathrm{~b}$ & $2.24 \mathrm{a}$ & $2.20 \mathrm{a}$ & $1.73 \mathrm{ab}$ \\
\hline$\sigma_{\mathrm{A} \mid 2}^{2}$ & $116.33 \pm 72.63$ & $269.19 \pm 67.52$ & $381.73 \pm 97.25$ & $212.40 \pm 72.34$ \\
\hline Gs & 3.05 & 8.74 & 10.25 & 6.08 \\
\hline Gs $\%$ & 4.76 & 11.32 & 9.06 & 4.46 \\
\hline
\end{tabular}

${ }^{\#} \mathrm{~F}$ values followed by the same letter in the row do not differ by Schumann-Bradley test at $5 \%$

compared to values found in the literature. This could indicate a low potential for the improvement of this trait in the ESA23B population. These values were similar to that obtained for the Piranão VF-1 population, 0.049 (Silva, 1990). Other estimates obtained for Brazilian populations of maize varied between 0.079 and 1.352, for data in percentage (Bianco, 1984; Zimback, 1986; Zanotto, 1986; Silva, 1990). However, estimates obtained for the cited authors belong to intrapopulation families, making comparisons difficult. Moreover, oil content is influenced by the xenia effect (Miller \& Brimhall, 1951; Alexander \& Lambert, 1968; Letchworth \& Lambert, 1998). Therefore, its evaluation in wind-polinated seeds tends to reduce differences among testcrosses because of the mixture of pollen from all treatments that occurs in the field.

The variation for protein content, measured as percentage, was higher than for oil content. The values were superior to those obtained by Zimback (1985) for two subpopulations of Braquítico-Opaco VD Composite ( 0.57 and 0.55 , data in percentage) and by Tosello \& Geraldi (1980) for the population ESALQ VD Opaco $(0,31)$. This fact, associated to the detection of some families with higher protein content than the best check, indicates a great potential for protein improvement in this population. Estimates obtained for ear and grain yield indicate the possibility of additional selection for yield.

Based on theoretical studies, Allison \& Curnow (1996) suggested that the best tester would be a homozygote recessive line or a population with low allelic frequency for the most important loci. Several authors succeeded in the selection with the use of endogamic lines with low per se values to the traits of interest as testers (Horner et al., 1973; Charcosset et al., 1990). The tester BR 108 is a productive cultivar and well adapted to Brazilian conditions, while CML269 is an exotic endogamic line. However, this fact did not seem to be determinant for the ability of the testers to discriminate families. More likely, for ear and grain yield, the estimate of the interpopulation additive variance obtained for the experiment with the BR 108 tester at Anhembi was not significant because of the high experimental error, as previously discussed.

The expected genetic gain for each trait was estimated based on selection intensity of $10 \%$. This intensity of selection was chosen in order to facilitate comparisons with results of the literature. However, considering the number of studied families, it would be better to use a less intense selection to avoid excessive reduction of the effective size of the population, that tends to 
reduce gains in the next cycles of recurrent selection. It should be noted that the estimated genetic gain refers to the interpopulation hybrid.

The highest estimates of genetic gain occurred for yield traits, with a maximum of $11.32 \%$ for grain yield in the experiment with the tester CML 269 at Anhembi (Table 8 ). Genetic gain estimates for protein content varied from 4.07 to $8.97 \%$, representing, in absolute values, 0.40 to 0.93 percentile points. These gains are similar to those reported by Woodworth et al. (1952) for five cycles of intrapopulacional recurrent selection, 5.2\%. Zimback (1985) calculated expected gains of 5.65 and $6.44 \%$ for protein content in two populations. The lowest estimates of genetic gain were observed for oil content (Table 8). However, gains from 1.83 to $3.56 \%$ are expected in the first cycle of selection, corresponding, in absolute values, to 0.09 and 0.16 percentile points. These gains are similar to those obtained for population IHO and inferior to those of the Zhongzong population n.2 (Dudley \& Lambert, 1992; Song et al., 1999). In percentile terms, these gains were superior to those obtained by Batista (1980) with selection for embryo size. It is noteworthy that gains reported in the literature were estimated for different methods of intrapopulation selection, differently from the results reported for the population of this work.

Phenotypic correlation analysis allowed to detect associations between some of the studied traits (Table 9). As expected, ear yield and grain yield were strongly correlated. Protein and oil content were correlated in all the experiments, but with low values, $(0.21$ to 0.41$)$. Oil content was also correlated with ear and grain yield; however, only in experiments involving the tester BR 108 and with low values. Associations between protein and oil content

Table 9 - Phenotypic correlations among the traits protein content, oil content, ear yield (EY) and grain yield (GY) at Anhembi (above diagonal) and Caterpillar (below diagonal).

\begin{tabular}{lcccc}
\hline & Protein & Oil & EY & GY \\
\hline Protein & & & & \\
BR 108 & & $0.2070^{*}$ & -0.0011 & -0.0040 \\
CML269 & & $0.4060^{*}$ & 0.0301 & -0.0508 \\
Oil & & & & \\
BR 108 & $0.2305^{*}$ & & $0.1870^{*}$ & $0.2038^{*}$ \\
CML269 & $0.3461^{*}$ & & 0.0447 & -0.0165 \\
EY & & & & \\
BR 108 & 0.0073 & $0.2547^{*}$ & & $0.9783^{*}$ \\
CML269 & 0.1043 & 0.0964 & & $0.9728^{*}$ \\
GY & & & & \\
BR 108 & -0.0259 & $0.2300^{*}$ & $0.9793^{*}$ & \\
CML269 & 0.0162 & 0.0781 & $0.9320^{*}$ & \\
\hline
\end{tabular}

significant at $5 \%$. varied from not significant (Dorsey-Redding et al., 1991; Séne et al., 2001) to highly positive values (Song et al., 1999). Negative correlations between oil content and yield in maize are frequently found in the literature, suggesting an unlikely simultaneous selection for both traits (Misevic \& Alexander, 1989; Tatis, 1990; Dudley \& Lambert, 1992). On the other hand, the ability of the plant to produce carbohidrates and to synthesize oil are physiologically independent in the interval of 4 to $7 \%$ of oil (Alexander \& Lambert, 1968). However, associations found here occur in a favorable direction, indicating a facility for the simultaneous selection of quality and yield traits. The correlation measures presented here are for the testcrosses (family $\mathrm{S}_{1} \mathrm{x}$ tester) and can eventually differ from estimates of the coefficient of correlation between genotypes for populations in equilibrium.

\section{CONCLUSIONS}

There is variability within the ESA23B population for protein and oil content, and for ear and grain yield; however, the ranking of the families is influenced by the tester and location, indicating that the selection should be made for each experiment separately. Estimates of interpopulation additive variance and the genetic gain indicate that there is potential for improvement of the four evaluated traits. Associations between traits are weak and in a favorable direction, indicating the possibility of simultaneous selection of the testcrosses for quality and yield traits.

\section{REFERENCES}

ALEXANDER, D.E.; LAMBERT, R.J. Relationship of kernel oil content to yield in maize. Crop Science, v.8, p.273-274, 1968.

ALLISON, J.C.S.; CURNOW, R.W. On the choice of tester parent for the breeding of synthetic varieties of maize (Zea mays L.). Crop Science, v.6, p.541-544, 1966.

ASSOCIATION OF OFFICIAL ANALYTICAL CHEMISTS Official methods of analysis of AOAC International. 16.ed. Washington, 1995. $1141 \mathrm{p}$.

BATISTA, L.A.R. Seleção para tamanho do embrião relacionada com o teor de óleo do grão de milho. Piracicaba: USP/ESALQ, 1980. 72p. (Dissertação - Mestrado)

BATISTA, L.A.R.; TOSELLO, G.A. Influência da fonte polinizadora sobre o conteúdo de óleo em grãos de milho. Pesquisa Agropecuária Brasileira, v.17, p.1757-1762, 1982.

BERKE, T.G.; ROCHEFORD, T.R. Quantitative trait loci for flowering, plant and ear height, and kernel traits in maize. Crop Science, v.35, p.1542-1549, 1995.

BIANCO, S. Avaliação do potencial genético de populações de milho (Zea mays, L.) braquítico para o teor de óleo na semente. Piracicaba: USP/ ESALQ, 1984. 98p. (Dissertação - Mestrado)

CHARCOSSET, A.; LEFORT-BUSON, M.; GALLAIS, A. Use of top-cross designs for predicting performance of maize single cross hybrids. Maydica, v.35, p.23-27, 1990.

DAVIS, R.L. Report of the plant breeder. Reports of Puerto Rico Agricultural Experimental Station, p.14-15, 1927.

DORSEY-REDDING, C.D.; HURBURGH JR., C.R.; JOHNSON, L.A.; FOX, S.R. Relationships among maize quality factors. Cereal Chemistry, v.68, p.602-605, 1991. 
DUDLEY, J.W. Seventy-six generations of selection for oil and protein percentage in maize. In: INTERNATIONAL CONFERENCE ON QUANTITATIVE GENETICS, Ames, 1976. Proceedings. Ames: Iowa State University Press, 1977. p.459-473.

DUDLEY . J.W.; LAMBERT, R.J. Ninety generations of selection for oil and protein in maize. Maydica, v.37, p.81-87, 1992.

EAST, E.M.; JONES, D.F. Genetic studies on the protein content of maize. Genetics, v.5, p.543-610, 1920.

EMBRAPA. Tabela de composição química e valores energéticos de alimentos para suínos e aves. Concórdia: EMBRAPA, CNPSA, 1991. 97p. (Documentos, 19)

GARWOOD, D.L.; WEBER, E.J.; LAMBERT, R.J.; ALEXANDER, D.E. Effect of different cytoplasms on oil, fatty acids, plant height, and ear height in maize (Zea mays L.). Crop Science, v.10, p.39-41, 1970.

GENTER, C.F.; EHEART, J.F.; LINKOUS, W.N. Effects of location, hybrid, fertilizer, and rate of planting on the oil and protein contents of corn grain. Agronomy Journal, v.48, p.63-67, 1956.

HORNER, E.S.; LUNDY, H.W.; LUTRICK, M.C.; CHAPMAN, W.H. Comparison of three methods of recurrent selection in maize. Crop Science, v.13, p.485-489, 1973.

JENKINS, M.T.; BRUNSON, A.M. Methods of testing inbred lines of maize in crossbred combinations. Journal of the American Society of Agronomy, v.24, p.523-30, 1932.

LETCHWORTH, M.B.; LAMBERT, R.J. Pollen parent effect on oil, protein, and starch concentration in maize kernels. Crop Science, v.38, p.363367,1998

MICU, V.E.; PARTAS, V.E.; ROTARI, A.I. The revealing and selection of high protein sources of maize. Maize Genetics Cooperation Newsletter, v.69, p. $115,1995$.

MILLER, P.A.; BRIMHALL, B. Factors influencing the oil and protein content of corn grain. Agronomy Journal, v.43, p.305-311, 1951.

MIRANDA FILHO, J.B.; GORGULHO, E.P. Cruzamentos com testadores e dialelos. In: NASS, L.L.; VALOIS, A.C.C.; MELO, I.S. de; VALADARES-INGLIS, M.C. (Ed.) Recursos genéticos e melhoramento: plantas. Rondonópolis: Fundação MT, 2001. cap.21, p.649-671.

MISEVIC, D.; ALEXANDER, D.E. Twenty-four cycles of phenotypic recurrent selection for percent oil in maize: I. Per se and test-cross performance. Crop Science, v.29, p.320-324, 1989.

OIKEH, S.O.; KLING, J.G.; OKORUWA, A.E. Nitrogen fertilizer management effects on maize grain quality in the West African moist savanna. Crop Science, v.38, p.1056-1061, 1998.
SCHUMANN, D.E.W.; BRADLEY, R.A. The comparison of the sensitivities of similar experiments: Model II of the analysis of variance. Biometrics, v.15, p.405-416, 1959.

SÉNE, M.; THÉVENOT, C.; HOFFMANN, D.; BÉNÉTRIX, F.; CAUSSE, M.; PRIOUL, J.-L. QTLs for grain dry milling properties, composition and vitreousness in maize recombinant inbred lines. Theoretical and Applied Genetics, v.102, p.591-599, 2001.

SILVA, S.O. Estimativas de parâmetros genéticos em populações de milho braquítico, pelo delineamento I e suas implicações no melhoramento do teor de óleo do grão. Piracicaba: USP/ESALQ, 1990. 136p. (Tese Doutorado)

SONG, T.M.; KONG, F.; LI, C.J.; SONG, G.H. Eleven cycles of single kernel phenotypic recurrent selection for percent oil in Zhongzong no. 2 maize synthetic. Journal of Genetics and Breeding, v.53, p.31-35, 1999.

SREERAMULU, C.; BAUMAN, L.F. Yield components and protein quality for opaque-2 and normal diallels of maize. Crop Science, v.10, p.262$265,1970$.

TATIS, H.A. Seleção para alto teor de óleo na semente de milho e seus efeitos sobre caracteres agronomic. Piracicaba: USP/ESALQ, 1990. 118p. (Tese - Doutorado)

TOSELLO, G.A.; GERALDI, I.O. Estimativas de parâmetros genéticos e fenotípicos para caracteres da planta e da qualidade do grão na população de milho ESALQ-VD opaco. Relatório Científico do Departamento de Genética, v.14, p.183-90, 1980.

U.S. GRAIN COUNCIL. 1998-1999 Value-Enhanced Corn Quality Report: Building global markets for America's grains. Washington, 1999. 123p.

WOODWORTH, C.M.; LENG, E.R.; JUGENHEIMER, R.N. Fifty generations of selection for protein and oil in corn. Agronomy Journal, v.44, p.60-65, 1952

ZANOTTO, M.D. Variabilidade genética e endogamia em duas populações de milho (Zea mays L.) contrastantes para teor de óleo. Piracicaba: USP/ ESALQ, 1986. 62p. (Dissertação - Mestrado)

ZIMBACK, L. Estimação de parâmetros genéticos e fenotípicos em uma variedade de milho dentado braquítico opaco (Zea mays L.). Piracicaba: USP/ESALQ, 1985. 169p. (Dissertação - Mestrado)

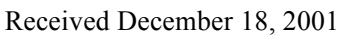

